\title{
A NEW BEE OF THE GENUS ANDRENA VISITING SENECIO
}

\author{
By T. D. A. Cockerell, \\ University of Colorado, Boulder, Colo.
}

In a large genus like Andrena, the discovery of a new species excites little interest, but the one now recorded has rather special claims. At Winfrith, Dorset, in England, on April 20, 1921, my wife and I had the pleasure of collecting both sexes of the beautiful Andrena (Trachandrena) albicans Müller. When I put the specimens away in the Trachandrena box, I remarked that whereas the North American fauna was rich in this group, there was nothing quite so beautiful as the English cousin, with bright red hair on the thorax above, white hair on the pleura, and bandless abdomen. However, on May 17, 1927, Mr. Chas. Wagner, one of my students, captured an Andrena on Senecio flowers at White Rocks, near Boulder, Colorado. When he brought it in, I said, "Where have you been? You must have been to England!" Superficially, it was just like A. albicans, though closer inspection showed various differences, thus the pleura is black haired, and the hair at end of abdomen is black, not red. It may be described thus:

\section{Andrena seneciophila n. sp.}

Female. Length nearly $11 \mathrm{~mm}$; a typical member of the subgenus Trachandrena; black, including antennæ and legs, tegulæ brown; head ordinary, face broad; process of labrum broadly truncate; malar space linear; clypeus coarsely and quite closely punctured, the punctures tending to run in longitudinal lines, apical third with a median smooth line; facial foveæ seen from above seal brown, running close to eyes separated by a shining band, extending downward to level of top of clypeus; third antennal joint not quite as long as next two together; hair of head thin, mostly black, but red on occiput, and slightly reddish in region about antennæ; mesothorax and scu- 
tellum dull and densely punctured, the surface covered with short stiff very bright fox-red hair, which also covers postscutellum, and extends down sides of thorax to cover tubercles and immediately adjacent parts; sides of metathorax with pale hair, which carries a great quantity of the orange Senecio pollen; mesopleura with black hair; wings dusky, darker apically; stigma well developed, rufo-piceous; nervures dark brown; second cubital cell broad, receiving recurrent nervure a little beyond middle; legs with black hair, spurs brown; abdomen shining, finely and rather closely punctured, without bands, hair at apex black; second segment depressed more than half, but hardly two-thirds. The area of metathorax is broadly triangular, with about sixteen strong longitudinal rugæ. The tongue is remarkably short, broad and pointed.

The problem of the independent production of superficially similar species of insects is an interesting one. I do not know whether the two species just discussed are really very closely related, but they are at any rate both Trachandrena. In California, there is another species with the same appearance, $A$. macrocephala Ckll., the female of which was taken by $\mathrm{Mr}$. Timberlake at Riverside, at flowers of Phacelia distans, March 8. This even agrees wit $A$. seneciophile in the black-haired pleura and black hair at end of abdomen. Yet it is not even a Trachandrena, and the structure of metathorax and second abdominal segment are entirely different. In the Mediterranean region, there is a Senecio-visiting species, $A$. senecionis Pérez. I have it from Spezia, Italy (Morice). It has rufescent dorsal hair, but is not a Trachandrena. 

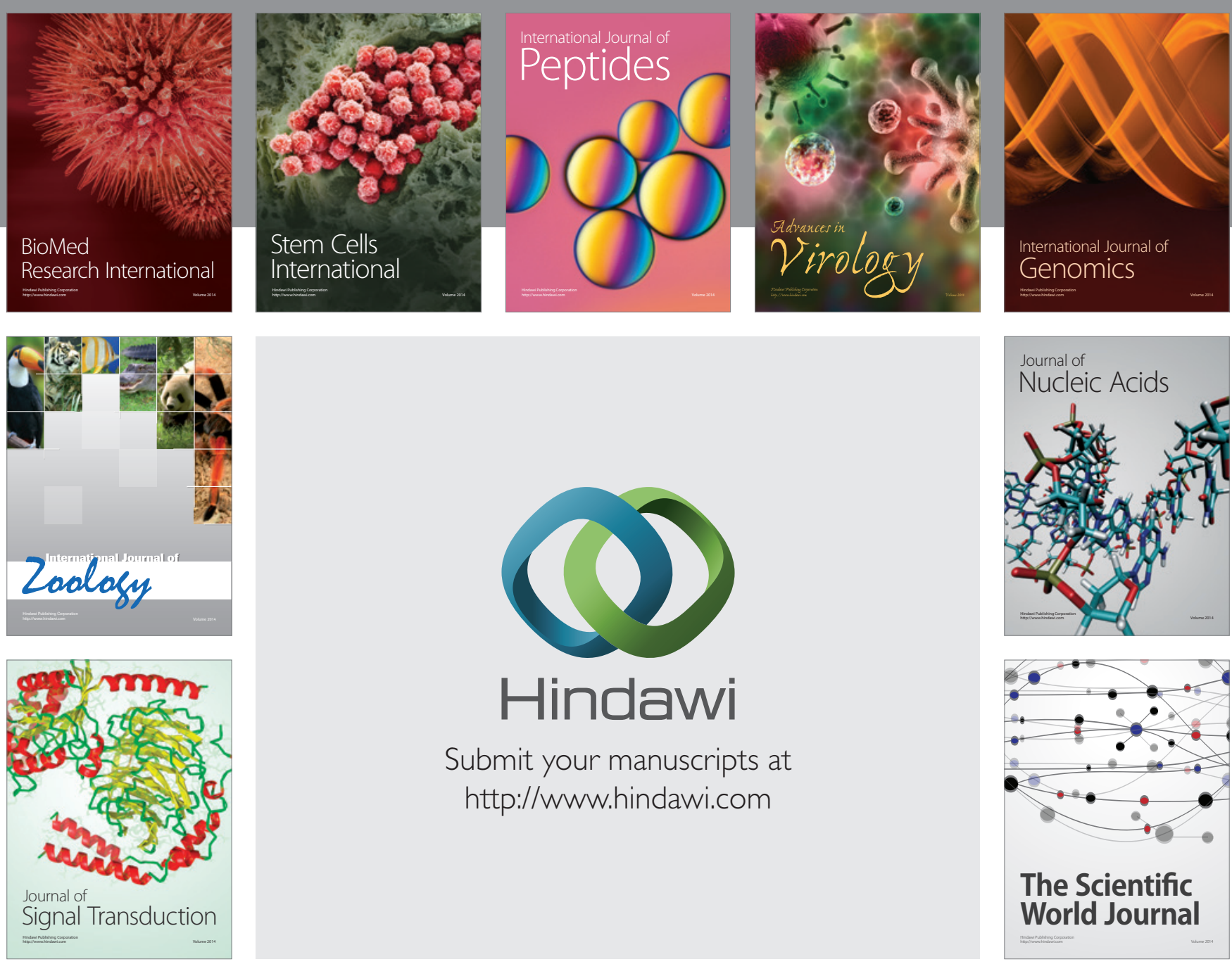

Submit your manuscripts at

http://www.hindawi.com
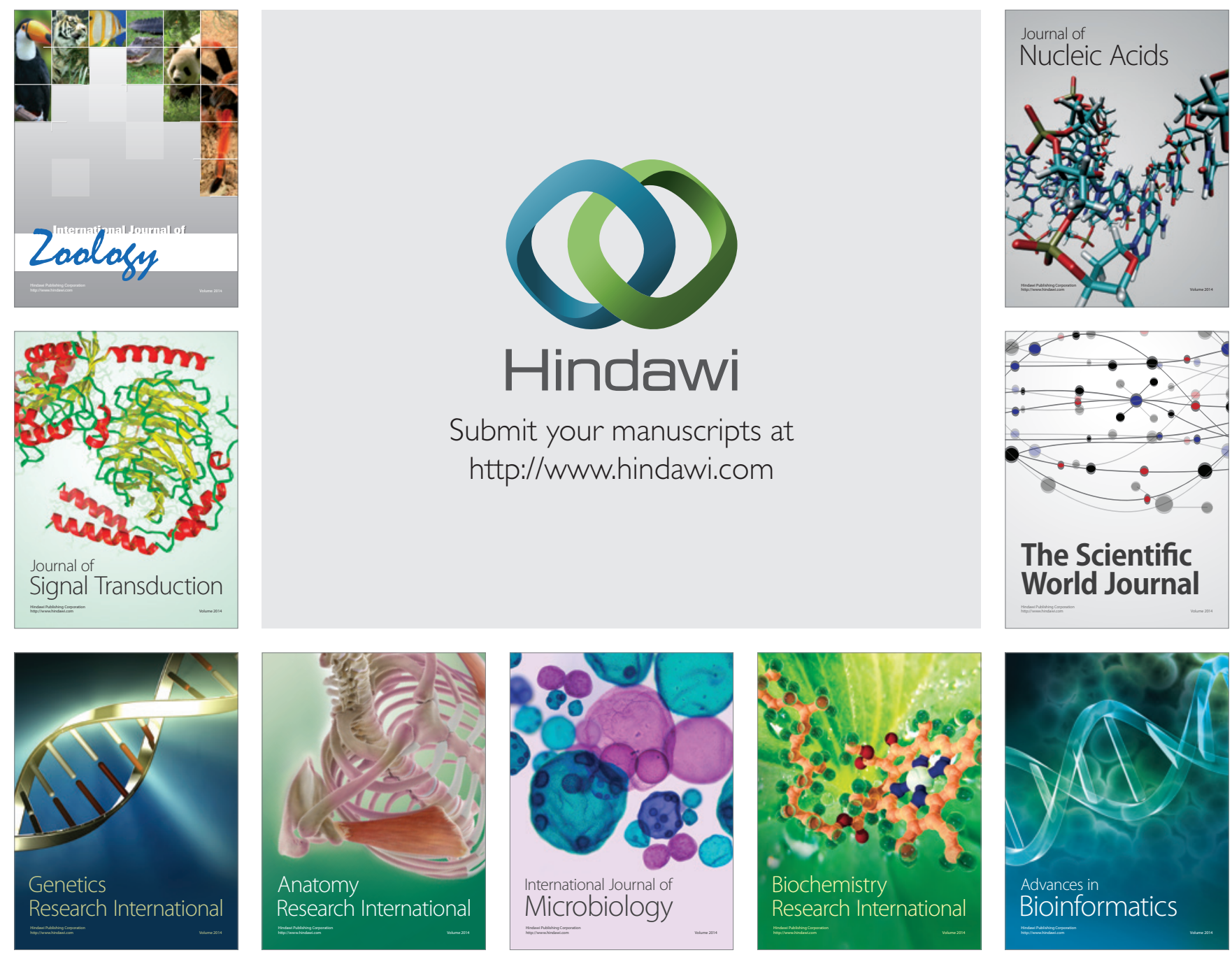

The Scientific World Journal
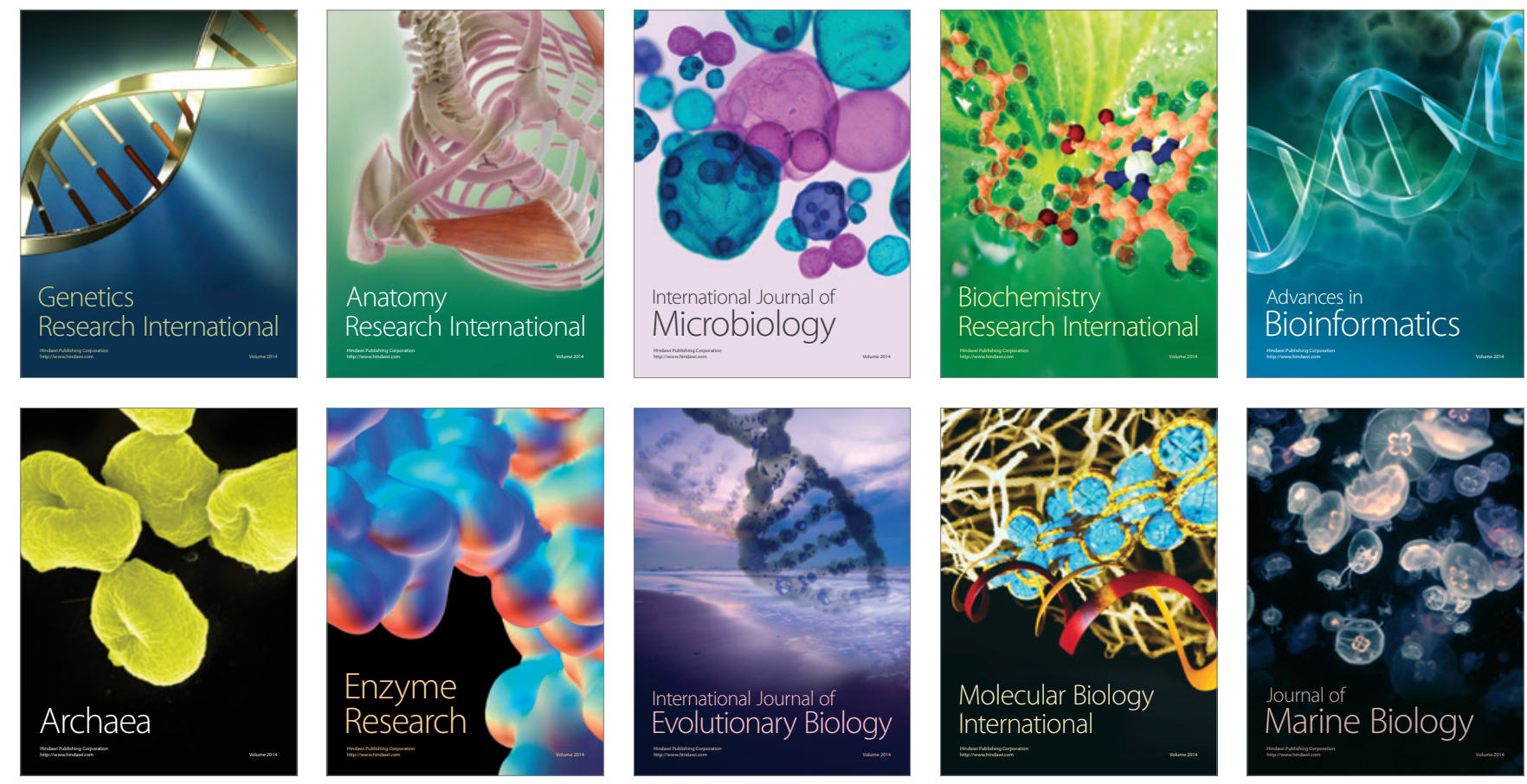